\title{
Pengaruh Pola Asuh Orang Tua Terhadap Perkembangan Kognitif Anak Usia 2 - 7 Tahun Di Gereja Toraja Jemaat Tello Batua Makassar
}

\author{
Fenty Apriani Hardy
}

\begin{abstract}
Abstrak
Skripsi ini ditulis untuk mengetahui sejauh mana pengaruh pola asuh orang tua terhdap perkembangan kognitif anak usia 2 - 7 tahun di Gereja Toraja Jemaat Tello Batua. Adapun kesimpulan penelitian ini adalah Pertama, pola asuh orang tua sangat penting karena sangat memengaruhi perkembangan anak, maka dari itu orang tua harus memberikan pola asuh yang baik dan tepat. orang tua harus bersama-sama bertanggung jawab dalam mengasuh dan mendidik anak karena anak sangat membutuhkan kedua orang tuanya. Kedua, orang tua harus menjalankan tugas dan tanggung dalam hal mengasuh atau mendidik anak yang merupakan perintah dari Allah sehingga orang tua harus meyakini, memahami bahwa Firman Tuhan adalah pedoman yang terbaik dalam mendidik atau mengasuh anak. Ketiga, anak yang berbeda tempat tinggal dengan orang tua akan mengalami masalah dalam segala aspek perkembangannya, khususnya pada perkembangan kognitif berbeda dengan anak yang diasuh oleh orang tua yang lengkap.

Kata-kata Kunci: Pola Asuh, Orang Tua, Anak, Perkembangan Kognitif, Gereja Toraja
\end{abstract}

\section{Pendahuluan}

\section{Latar Belakang Masalah}

Orang tua memegang peranan yang sangat penting dalam mengasuh, membesarkan dan mendidik anak karena Allah sendiri yang memberikan perintah kepada orang tua ".....tetapi didiklah mereka di dalam ajaran dan nasihat Tuhan." (Efesus 6:4). Maka dari itu, orang tua sebagai wakil dari Allah yang telah diberikan perintah khusus harus mampu menjalankan tugas dan peran sebagai orang tua.

Suatu kebanggaan menjadi orang tua karena orang tua mengemban tugas yang mulia, sama seperti yang dikatakan oleh Singgih D. Gunarsa dan Yulia 
Singgih D. Gunarsa dalam bukunya Psikologi Perkembangan Anak dan Remaja mengatakan bahwa:

Mengasuh, membesarkan dan mendidik anak merupakan satu tugas mulia yang tidak lepas dari berbagai halangan dan tantangan. Telah banyak usaha yang dilakukan orang tua maupun pendidik untuk mencari dan membekali diri dengan pengetahuan-pengetahuan yang berkaitan dengan perkembangan anak $^{1}$

Dalam menjalankan tugas dan perannya orang tua menghadapi banyak tantangan tetapi sebagai pendidik orang tua terus berusaha menjadi orang tua terbaik bagi anaknya dalam mengasuh, membesarkan dan mendidik anak. Orang tua mengharapkan anak mereka bisa menjadi orang yang sukses. Begitu banyak upaya yang orang tua lakukan untuk dapat mencapai tujuannya, ada yang tidak berhasil, ada yang berhasil, tetapi dengan akibat sampingan. Banyak orang tua menjadi orang tua tanpa mengalami persiapan untuk menjadi orang tua, hal tersebut terlihat dengan bagaimana cara mereka mendidik atau mengasuh anak mereka. Banyak cara mendidik yang dilakukan orang tua mengikuti pola pendidikan yang dialaminya sendiri, hasil didikan yang sama diterapkan zaman yang berbeda. Seolah-olah anak menjadi kelinci percobaan dalam usaha mendidik dan mengasuh anak. $^{2}$

Orang tua mempunyai masalah dengan pola asuh anak karena adanya perbedaan tempat tinggal ayah dan ibu dengan anak, Tanggung jawab mengasuh atau mendidik anak seharusnya dilakukan secara bersama-sama antara ibu dan ayah bukan hanya sebelah pihak saja. Tetapi ada kalanya tuntutan pekerjaan membuat ayah dan ibu harus terpisah tempat tinggal dengan keluarga. Keputusan berat itu mesti diambil demi masa depan yang lebih baik dan dari pilihan itu ada konsekuensi yang orang tua harus hadapi. Anak akan merasakan ketiadaan ayah atau ibu di rumah, kehilangan sosok yang sangat disayanginya. Salah seorang dari orang tua memegang peran ganda. ${ }^{3}$ Meskipun anak sangat membutuhkan kedua orang tuanya, tetapi pada kenyataannya anak merasakan ketiadaan ayah atau ibu. Seorang ayah harus dapat mengerti keadaan anak, bertindak sebagai teman dan rekan bagi

\footnotetext{
${ }^{1}$ Singgih D. Gunarsa dan Yulia Singgih D. Gunarsa, Psikolgi Perkembangan Anak dan Remaja (Jakarta: BPK Gunung Mulia, 1983), 3.

${ }^{2}$ Singgih D. Gunarsa dan Yulia Singgih D. Gunarsa, Psikolgi Praktis: Anak, Remaja dan keluarga (Jakarta: BPK Gunung Mulia, 1993), 24-25.

3 “Tinggal Berjauhan dengan Pasangan, Apa Resikonya?" diakses 4 April 2016, http://www.republika.co.id/berita/humaira/samara/13/01/30/mhffre-tinggal-berjauhan-dengan pasangan-apa-risikonya.
} 
anak-anaknya, membimbing perkembangan anak serta melakukan sesuatu untuk dan bersama-sama anak-anaknya. ${ }^{4}$

Sangatlah jelas bahwa, bukan hanya ibu saja yang bertanggung jawab menjalankan peran mereka sebagai orang tua, tetapi ayah juga sebagai kepala keluarga yang menafkahi keluarga harus dapat membimbing perkembangan anak serta harus memiliki waktu yang berkualitas bersama anak.

Kedua sosok orang tua mempunyai peranan yang sama penting untuk itu, relasi yang baik antara orang tua yang berbeda tempat tinggal dengan anak harus tetap terjaga, orang tua harus tetap memenuhi segala segi kebutuhan anak. Keluarga menjadi tidak harmonis ketika salah satu orang tua seolah menghilang. Oleh karena itu, hubungan yang hangat antaranggota keluarga mesti tetap terjalin. Meski tidak hadir secara fisik, tetapi orang tua harus mampu berkomunikasi dengan hangat dan menyentuh perasaan anak. ${ }^{5}$

Orang tua yang berbeda tempat tinggal dengan anaknya akan membawa pengaruh pada perkembangan anak secara umum. Khususnya pada perkembangan kognitif anak yaitu, anak kurang mendapat pengontrolan dari kedua orang tuanya khususnya dalam perkembangan kognitif, kemampuan pengetahuan anak menjadi sangat lambat berbeda dengan teman sebanyanya yang diasuh atau dididik langsung oleh kedua orang tua lengkap. Seorang ibu atau ayah memegang peranan ganda sehingga untuk membantu anak dalam memenuhi kebutuhan perkembangannya khususnya dalam segi kognitif sangat kurang. ${ }^{6}$

Abu Ahmadi dan Nur Uhbyati mengungkapkan bahwa:

Pendidikan adalah karena dorongan orang tua yaitu, hati dan nuraninya yang terdalam yang mempunyai sifat kodrati untuk mendidik anaknya baik dalam segi fisik, sosial, emosi maupun intelegensinya agar memperolah keselamatan kepandaian agar mendapat kebahgiaan hidup yang mereka idamidamkan, sehingga ada tanggung jawab moral atas hadirnya anak tersebut yang diberikan oleh Tuhan Yang Maha Kuasa untuk dapat dipelihara dan dididik dengan sebaik-baiknya. ${ }^{7}$

Maka dari itu, orang tua harus memperhatikan pola asuh yang tepat diberikan kepada anak. Karena anak adalah anugerah dari Tuhan, anak lahir dalam

\footnotetext{
${ }^{4}$ Singgih D. Gunarsa dan Yulia Singgih D. Gunarsa, Psikolgi Perkembangan Anak dan Remaja (Jakarta: BPK Gunung Mulia, 1983), 154.

5 “Tinggal Berjauhan dengan Pasangan, Apa Resikonya?" diakses pada tanggal 4 April 2016, http://www.republika.co.id/berita/humaira/samara/13/01/30/mhffre-tinggal-berjauhandenganpasangan-apa-risikonya

6 “Tinggal berjauhan dengan pasangan, Apa Resikonya?" diakses 4 April 2016, http://www.republika.co.id/berita/humaira/samara/13/01/30/mhffre-tinggal-berjauhan-dengan pasangan-apa-risikonya.

${ }^{7}$ Abu Ahmadi dan Nur Uhbyati, Ilmu Pendidikan (Jakarta: PT Rineka Cipta, 1991), 74.
} 
pemeliharaan orang tua dan dibesarkan di dalam keluarga. Orang tua memikul tugas sebagai pendidik, ia harus bertanggung jawab baik bersifat sebagai pemelihara, sebagai pengasuh, sebagai pembimbing, sebagai pembina maupun sebagai guru dan pemimpin terhadap anak-anaknya.

Orang tua berkewajiban untuk memperhatikan anaknya serta mendidiknya, sejak anak itu kecil bahkan sejak anak dalam kandungan. Karena didikan dari sejak kecil itu akan diingatnya sampai anak itu menjadi orang yang dewasa. Tetapi pada kenyataannya di gereja toraja jemaat tello batua, orang tua tidak dapat menjalankan tugas dan perannya secara maksimal karena pengaruh perbedaan tempat tinggal ayah dan ibu yang berbeda, orang tua malah terlalu sibuk dengan pekerjaan mereka, seperti pada kasus yang terjadi ada 30 orang tua yang berbeda tempat tinggal dengan anak, sehingga orang tua kurang memperhatikan perkembangan kognitif anaknya, tidak heran jika banyak anak mengalami perkembangan yang lambat dari teman-teman sebayanya yang diasuh dengan orang tua lengkap. Adapun masalah kognitif yang dapat dialami anak yaitu, misalnya secara umum anak mengalami kesulitan untuk belajar, tidak memiliki daya ingat yang baik atau dapat menghapal dengan baik, nilai akademik kurang, dan lain sebagainya. Secara khusus masalah kognitif yang dihadapi anak yaitu, tidak dapat mengetahui dan menyebutkan umur mereka, kurang memahami huruf dan angka, tidak dapat memasangkan dan menyebutkan benda yang sama, dan lain sebagainya. Dengan masalah demikian perlu adanya pola asuh yang ideal bagi anak untuk mendukung perkembangan kognitifnya. Selain itu salah satu masalah perkembangan kognitif yang banyak muncul adalah gangguan kesulitan pemusatan perhatian.

Para orang tua pasti menginginkan anaknya mengalami perkembangan kognitif sesuai dengan tahap, tetapi yang terjadi dilapangan orang tua mengalami masalah dalam mengasuh dan mendidik anaknya, anak tidak mendapat pola asuh yang menyeluruh oleh kedua orang tuanya, seperti seorang ayah yang sibuk bekerja diluar kota meninggalkan seorang isteri dan anaknya, sehingga mereka terpisah oleh karena jarak pekerjaan. Siap atau tidak ibu seorang diri mengasuh dan mendidik anaknya karena ayah berbeda temoat tinggal dikarenakan bekerja diluar kota.

Orang tua sedang bergumul untuk menyeimbangkan tuntutan pekerjaan dan kehidupan keluarga yang saling bersaing. Semua orang tua adalah orang tua pekerja tetapi bukan hanya dalam pengertian bekerja untuk mendapatkan upah. waktu bersama dengan anak menjadi sangat kurang. Banyak ibu dan ayah tidak mempunyai pilihan selain bekerja purnawaktu untuk mencukupi kebutuhan hidup mereka. Mereka bekerja karena kebutuhan bukan pilihan. Namun ada pula orang tua yang bekerja karena pilihan. Orang tua sangatlah berfokus hanya pada untuk memenuhi kebutuhan anak tanpa memikirkan waktu bersama dengan anak dalam mengasuh dan mendidik anak. ${ }^{8}$

\footnotetext{
${ }^{8}$ Steve Chalke, Orang Tua Karir (Yogyakarta: ANDI, 2006), 5.
} 
Anak-anak, khususnya yang masih sangat kecil mempunyai tuntutan waktu sangat besar terhadap orang tuanya. Mereka perlu mendapat pola asuh yang menyeluruh dari kedua orang, tetapi orang tua tidak dapat menjalankan tugas dan tanggung jawabnya dengan baik karena pengaruh tempat tinggal ayah dan ibu yang berbeda sehingga memengaruhi perkembangan kognitif anak.

\section{Pokok Masalah}

Dari latar belakang di atas, maka yang menjadi pokok masalah dalam penulisan skripsi ini adalah sejauh mana pengaruh pola asuh orang tua, khususnya orang tua yang berbeda tempat tinggal terhadap perkembangan kognitif anak usia 2 - 7 tahun di Gereja Toraja Jemaat Tello Batua?

\section{Tujuan Penelitian}

Skripsi ini di tulis oleh penulis untuk mengetahui sejauh mana pengaruh pola asuh orang tua terhdap perkembangan kognitif anak usia 2 - 7 tahun di Gereja Toraja Jemaat Tello Batua.

\section{Manfaat Penelitian}

Dalam skripsi ini, ada beberapa manfaat yang ingin dicapai dalam penlisan skripsi ini, yaitu :

Pertama, menjadi bahan acuan bagi orang tua dimanapun berada secara khusus di Gereja Toraja Jemaat Tello Batua dalam mengetahui sejauh mana pengaruh pola asuh orang tua terhadap perkembangan kognitif anak.

Kedua, sebagai bekal penulis untuk mempersiapkan diri masuk kedalam pelayanan-Nya dan ketika akan menjadi orang tua dikemudian hari.

Ketiga, sebagai salah satu persyaratan dalam menyelesaikan pendidikan strata satu di Sekolah Tinggi Theologia Jaffray Makassar.

\section{Metode Penelitian}

Dalam skripsi ini Penulis menggunakan metode penelitian kuantitatif dengan menggunakan beberapa teknik pengumpulan data yaitu mancakup:

Pertama, kajian pustaka yaitu, dengan mengumpulkan data atau informasi dari buku-buku kepustakaan, jurnal dan internet yang berhubungan dengan pengaruh pola asuh orang tua terhadap perkembangan kognitif anak usia 2 - 7 tahun.

Kedua, menggunakan metode kuisioner (angket) ${ }^{9}$ tertutup yaitu, mengumpulkan data dengan menggunakan suatu daftar atau kumpulan pertanyaan tertulis yang harus di jawab secara tertulis juga kepada orang tua yang memiliki anak usia 2 -7 tahun yang berbeda tempat tinggal untuk mengetahui sejauh mana pengaruh pola asuh orang tua terhadap perkembangan kognitif anak.

\footnotetext{
${ }^{9}$ Hengki Wijaya (ed.), Metodologi Penelitian Pendidikan Teologi (Makassar: Sekolah Tinggi Theologia Jaffray, 2016), 26.
} 
Ketiga, melaui wawancara yaitu, mengumpulkan data dengan mengadakan komunikasi dilakukan dengan dialog (tanya jawab) kepada anak dan orang tua untuk menguatkan data angket serta kepada pengurus gereja untuk mengenal lokasi penelitian. ${ }^{10}$

Keempat, observasi dilakukan dengan mengadakan pengamatan langsung ke lokasi sebagai objek penelitian.

\section{Batasan Penelitian}

Penulis memberikan batasan untuk membahas hanya pada pengaruh pola asuh orang tua terhadap perkembangan kognitif, dalam hal ini orang tua yang berbeda tempat tinggal dengan anak yang berusia 2 - 7 tahun memengaruhi perkembangan kognitif anak.

\section{Kepustakaan}

Ahmadi, Abu dan Nur Uhbyati, Ilmu Pendidikan. Jakarta: PT Rineka Cipta, 1991.

Chalke, Steve. Orang Tua Karir. Yogyakarta: ANDI, 2006.

Gunarsa, Singgih D. dan Yulia Singgih D. Gunarsa, Psikologi Perkembangan Anak dan Remaja. Jakarta: BPK Gunung Mulia, 1983.

Gunarsa, Psikologi Praktis: Anak, Remaja dan keluarga. Jakarta: BPK Gunung Mulia, 1993.

Wijaya, Hengki (ed.). Metodologi Penelitian Pendidikan Teologi. Makassar: Sekolah Tinggi Theologia Jaffray, 2016.

Matheus, J., Elisabet Selfina. "Peran Pembina Remaja Bagi Perkembangan Perilaku Remaja Di Gereja Kemah Injil Indonesia Tanjung Selor Kalimantan Utara." Jurnal Jaffray 13, no. 1 (2015). http://dx.doi.org/10.25278/ji71.v13i1.3

Maruanaya, Vita O., Ivan Th. J Weismann. "Peran Orang Tua Terhadapa Perkembangan Pribadi Remaja Atas Pemanfaatan Internet di Kalangan Remaja di SMU Advent Makassar." Jurnal Jaffray 8, no. 1 (2010). http://dx.doi.org/10.25278/jij1.v8i1.41

Selfina, Elisabet. "Strategi Pertumbuhan Gereja Melalui Pendidikan Anak Usia Dini." Jurnal Jaffray 11, no. 1 (2013). http://dx.doi.org/10.25278/jij1.v11i1.65

\footnotetext{
${ }^{10}$ Hengki Wijaya (ed.), Metodologi Penelitian Pendidikan Teologi (Makassar: Sekolah Tinggi Theologia Jaffray, 2016), 24.
} 